\title{
NUP98/PHF23 Fusion Protein
}

National Cancer Institute

\section{Source}

National Cancer Institute. NUP98/PHF23 Fusion Protein. NCI Thesaurus. Code C99458.

A fusion protein (797 aa, $~ 82 \mathrm{kDa}$ ) encoded by the NUP98/PHF23 fusion gene. This protein is comprised of the N-terminal nucleoporin GLFG repeat domains of the nuclear pore complex protein Nup98-Nup96 protein fused to the C-terminal PHD domain of the PHD finger protein 23. 